\title{
The Effect of Competence, Infrastructure and Accessibility on Patients' Satisfaction at the Puskesmas in Kabupaten Indragiri Hulu
}

\author{
Astarman*a, Aris Triyono $^{\text {b }}$, Tomy Fitrio ${ }^{c}$ \\ ${ }^{* a, b, c}$ Economics Collage Indragiri (STIE-I) Rengat Indonesia \\ a: Sekolah Tinggi Ilmu Ekonomi Indragiri (STIE-I) Rengat \\ b: Sekolah Tinggi Ilmu Ekonomi Indragiri (STIE-I) Rengat \\ c: Sekolah Tinggi Ilmu Ekonomi Indragiri (STIE-I) Rengat
}

\begin{abstract}
This study aimed to analyze the effect of competency, infrastructure and accessibility on patients'satisfaction at Puskesmas (health centers) in Kabupaten Indragiri Hulu. The population in this study wasdaily visitors at three Puskesmas with unknown numbers. The number of samples was calculated by usingYamani formula and 97 respondents were taken as the samples. They were the patients who got treatment atthe Puskesmas in Kabupaten Indragiri Hulu. These sample were chosen through proportional randomsampling method. The data of this study were collected by distributing a closed questionnaire. Then, the datawere measured by using Likert scale. After that, the data were analyzed by employing SEM (StructuralEquation Modeling) analysis which was operated through Smart PLS 3 Application. The results of this studyindicated that: (1) Competence had a positive and significant effect on patients' satisfaction; (2)Infrastructure had a positive and significant effect on patients' satisfaction (3) Accessibility had a positiveand significant effect on patients' satisfaction.
\end{abstract}

\section{Keywords: Competence, Infrastructure, Accessibility, Patients’ Satisfaction.}

\section{Introduction}

Based on the number of medical staffs at Puskesmas in Kabupaten Indragiri Hulu, the patients' expectations have not been unfulfilled. There is an inequality between the number of medical staffs and the number of patients treated at the puskesmas. The ideal number of medical staff for doctors should be one doctor for 30 patients and each doctor is assistedd by a nurse. This can be seen from the table in the next discussion. Table 1 shows that there is a shortage of medical staffs in Kabupaten Indragiri Hulu. Although there is an increase in the number of medical staffs each year, it has not been able to cover and balance the number of patients treated in Puskesmas especially in Kabupaten Indragiri Hulu.

Realizing a healthy condition is the desire of all parties, not only by individuals, but also by families, groups and even the community. The implementation of health services for the community at the basic level in Indonesia is through the Community Health Center (Puskesmas) which is a functional organizational unit of the District Health Office. Puskesmas is given the responsibility to manage the community for each Kecamatan (sub-district) of the Kabupaten (district).

In this case, the goal of health development is to increase the awareness, willingness and ability to live healthy for everyone in order to realize an optimal degree of public health through the creation of a nation and state society. It is characterized by people who live in healthy environments and healthy life behaviors and also have the ability to reach a good and qualified health services fairly and evenly in accordance with the public policies and health development strategies.

An excellent service becomes a demand of the community as the need and awareness in the life of the state and society is increased. This occurs as an impact of the advancement of information technology. A high quality is a demand, not only in business activities but also in service activities of the government institutions that are resistant to the demands of public services quality. 
Improving health for the community is one of the sectors that Government is very concerned about, particularly in Kabupaten Indragiri Hulu, in terms of equitable distribution of health services with diverse geographical conditions and a population of 388,916 people. The Government of Indragiri Hulu, in this case, the Health Office of Kabupaten Indragiri Hulu, provides community service centers spread throughout the Kecamatan (sub-districts) in Kabupaten Indragiri Hulu; there are 14 kecamatan and 20 Puskesmas. Those 20 Puskesmas are Puskesmas Kuala Cinaku, Sipayung, Kambesko, Pekan Hera, Kasai Base, Siberida , Kilan, Lubuk Kandis, Lirik, Air Molek, Sungai Lala, Sungai Parit, Kulim Jaya, Polak Pisang, Medan City, Kota Baru, Rakit Kulim, Peranap, Batang Peranap, and Secano. Furthermore, the phenomena related to the existence of Medical and Non-Medical Staffs and the number of patients' visits can be seen in Table 1.

Table 1.

Data of Medical and Non-Medical Staff and Patients' Visits at Puskesmas in Kabupaten Indragiri Hulu from 2013 to 2017

\begin{tabular}{|l|l|r|r|r|r|r|}
\hline & & \multicolumn{5}{|c|}{ YEARS } \\
\hline NO & \multicolumn{1}{|c|}{ DESCRIPTION } & 2013 & 2014 & 2015 & 2016 & 2017 \\
\hline 1 & Medical staffs & & & & & \\
\hline & - Doctor & 50 & 52 & 53 & 54 & 56 \\
\hline & - Nurse & 210 & 225 & 245 & 253 & 265 \\
\hline & - Midwife & 124 & 135 & 138 & 138 & 138 \\
& & & & & \\
\hline 2 & Non-Medical staffs & & & & & 18 \\
\hline & - Head of Puskesmas & 18 & 18 & 18 & 18 & 18 \\
\hline & - Administration staffs & 42 & 42 & 42 & 42 & 42 \\
\hline & - Pharmacists & 3 & 3 & 3 & 3 & 3 \\
\hline & - Health Analysts & 20 & 20 & 26 & 28 & 29 \\
\hline & - Pharmacists Assistant & 34 & 34 & 34 & 34 & 35 \\
\hline & - Nutritionists & 29 & 29 & 29 & 32 & 32 \\
\hline & - Cleaning staffs & 30 & 30 & 37 & 37 & 40 \\
\hline 3 & Patient Visits & & & & & 182.100 \\
\hline & - Outpatient & 140.231 & 167.909 & 169.993 & 179.201 & 1.317. \\
\hline & - Inpatient & 1.291 & 1.344 & 1.325 & 1.453 & \\
& & & & & & \\
\hline
\end{tabular}

Source: the Health Office of Kabupaten Indragiri Hulu 2017

Based on the calculation of the number of Medical Staffs, the major problem of health services in Kabupaten Indragiri Hulu is the failure of patient expectations, which means that the number of medical staffs at puskesmas is inequal to the number of patients treated.

Table 1 displays the number of services and medical staffs available to offer services to the patients in 14 sub-districts and 20 puskesmas. In 2013, there were 50 doctors, 210 nurses 210 and 124 midwives. These medical staffs served 140,231 outpatients and 1,291 inpatients. In 2014, there was an increase in the number of the staffs, which were 2 doctors, 225 nurses, and 15 midwives. In this case, the medical staffs at puskesmas served 167.909 outpatients and 1,344 inpatients. After that, in 2015, there was an increase in the number of doctors (1 person) and midwives (3 people) while the additional quota for nurses was 20 people. By this number, the medical staffs at the puskesmas served 169,993 outpatients and 1,325 inpatients. Then, in 2016, there were 1 additional doctor and 8 additional nurses, so the medical staffs served 179,201 outpatients and 1,453 inpatients. In addition, in 2017, there was also an increase in the number of doctors $(2$ people) and nurses (12 people). There was no additional number for midwives at the puskesmas in 2016 and 2017 respectively. With this number, they could served 182,100 outpatients and 1,317 inpatients.

Patients' satisfaction is a process that can be achieved if the elements in the health service unit possess good competence. Excellent human resources and service systems are the principles to be able to provide benefits that can be enjoyed by patients in the form of satisfaction (Ririn, 2007). 
Increasing the satisfaction of patients and their families, the health service units, starting from the leadership and staffs/ employees, should understand and recognize the expectations of patients and their families. If the services offered can grant satisfaction to them, naturally they will be confident and trust in the health care unit. Therefore, every unit needs to understand what activities can be carried out and which can affect the level of patients' satisfaction, so patients will be satisfied with the service they receive (Saludung, 2002).

On one side, the competency of medical staffs is a technical element in the health services at Puskesmas (Alamsyah and Muliawati, 2013). The intended medical staffs include doctors, nurses and midwives. These 3 professions have job descriptions that are different from one to another, but the main goal is to provide health services to the community.

The competency of nurses, which consist of knowledge, expertise and behavior of workers, will produce a good service quality. The quality improvement is important both internally and externally because it will be reflected in the interaction of the organization with the environment which contributes to the organization's image in the eyes of various parties outside the organization (Siagian, 2002).

Furthermore, the employees/staffs at the Puskesmas are the supporting elements after the medical staffs (Alamsyah and Muliawati, 2013). Employees are assets that determine the good and bad things of the health services provided by the health centers to the community. The quality and quantity of the employees is equal to the variety of expertise/ professions existed at Puskesmas. The more employees, the more efficient and effective the service becomes because the service becomes fast, easy to find and directed. Besides, various types of health services can also be provided. Thus, the employee procurement is an important, difficult, and complex problem because getting and placing people who are competent and effective is not as easy as buying and placing machines (Hasibuan, 2008). A research by Faigah A. Badjamal (2014) found that competence influenced patients' satisfaction while Rahma Indrawati (2106) found that the competence and service quality of Puskesmas employees positively influenced the patients' satisfaction. Then, Karami Kabir Nahid et al. (2010) revealed that the types of staffs (nurses, doctors, students and others) demonstrated effective behavior on patient satisfaction; while the drug preparation done by patient guards were effective to the patients' dissatisfaction. After that, Rita Fahdila Sumantri (2012) asserts that learning management competencies directly affect the teachers' job satisfaction while Darlius (2015) conducted a study and revealed that the doctors' competence did not significantly influence patients' satisfaction.

The next service standards that become the supporting factors for the health service at puskesmas are Medical Infrastructure which have certain inadequate standards in which some additional infrastructure is required. This standard is a minimum requirement because an innovation form the head of health center is necessary to improve service quality. It covers medicine, medical support, up to date references of medical care protection, periodic medical reviews and the development of non-medical and other activities. (Muhammad: 2010). The totality of good infrastructure is very crucial in creating customers' satisfaction. A research conducted by Dela Purwandani, Cicih Sutarsih, Sururi (2016) found that there was a positive and significant relationship between the Quality of Service Facilities and Infrastructure towards Students' Satisfaction. Meanwhile, Alicia, Yanwir Kamal (2013), in her study, found that there was a relationship between the Administrative Services, Medical Services, and Infrastructure of Family Doctors and the satisfaction of Askes Sosial participants at PT. Askes (Persero). After that, The results of the hypothesis tested by Ida Yunari Ristiani (2017), concluded that there was a relationship and influence between infrastructure and patients' satisfaction. Next, Fardiansyah Ahmad, Irmayani, Adriani Kadir (2013) conducted a bivariate analysis and obtained the results which indicated that infrastructure influenced the level of patients' satisfaction.

Besides, there is also accessibility in terms of a measure of convenience or easiness regarding the way of land use location which interacts with each other. The easiness of the location being achieved through transportation network systems and accessibility is closely related to the availability and facility in getting good Puskesmas services. The research results of Afifah Audistiana, Muslichah Erma Widiana, Bramastyo Kusumo Negoro (2017) found that the variables accessibility, facilities and customers' satisfaction have a significant and simultaneous effect on customers' loyalty at Delta Fishing Sidoarjo. Metta Primaningtyas (2012) empirically asserts that accessibility factors, physical attributes, environmental health and public facilities are factors that influence the satisfaction of living in property developed by PT. Armada Hada 
Graha Magelang. Then, Mira Taufik et al. (2015) argue that patients' satisfaction is not due to regional accessibility; accessibility has an influence on customers' satisfaction.

Based on the background, observations, phenomena and theories, research gap and previous research that supports, the authors intended to conduct a research on "The Effect of Competence, Infrastructure and Accessibility on Patients' Satisfaction at Puskesmas in Kabupaten Indragiri Hulu ".

\section{Formulation of the Problem;}

1. Does Competence affect Patients' Satisfaction at Puskesmas in Kabupaten Indragiri Hulu?

2. Does Infrastructure affect Patients' Satisfaction at Puskesmas in Kabupaten Indragiri Hulu?

3. Does Accessibility affect Patients' Satisfaction at Puskesmas in Kabupaten Indragiri Hulu?

\section{Research purposes;}

1. To find out and analyze the influence of competency on patients' satisfaction at Puskesmas in Kabupaten Indragiri Hulu.

2. To find out and analyze the influence of infrastructure on patients' satisfaction at Puskesmas in Kabupaten Indragiri Hulu.

3. To find out and analyze the effect of accessibility on patients' satisfaction at Puskesmas in Kabupaten Indragiri Hulu.

\section{Reviews of Literature and Hypothesis \\ Customers' Satisfaction (Patients)}

According to Kotler (1997: 40), in Rangkuti (2003: 23), customers' satisfaction is "a person feeling of pelasure or disappointment resulting from comparing a product's received performance (or outcome) in relations to the person expectation". It means someone's feeling of happiness or disappointment as a result of a comparison between perceived and expected products or perceptions.

Customers' satisfaction is an effort made by a company to make the products or services promoted able to satisfy the customers' needs. Customers' satisfaction is a measure of how well the company is executing a business while self satisfaction is a function of performance and expectations. If performance meets expectations, customers will be satisfied. Conversely, if the performance does not meet expectations, the customer will feel dissatisfied (Prihantoro, 2012: 37). According to Howard and Sheth, in Tjiptono and Chandra (2005: 198), satisfaction is a cognitive situation of buyers who feel valued regardless of the sacrifices that have been made.

In this case, satisfaction is related to the patient's recovery from illness or injury. This is more connected to the consequences of the nature of health services; it is also related to the goals and results of the service. It is about the patients' satisfaction in evaluating the quality or good services as well as an important measurement that is fundamental to service quality. This is because it provides information on the success of qualified service providers with the value and expectations of patients who have their own authority to set the desired service quality standards (Hafizurrachman, 2004). Kotler (2007) defines patients' satisfaction as the level of someone's feelings after comparing the performance (or results) that he feels to his expectations. According to Gerson (2004), patient satisfaction is the patient's perception that his expectations have been fulfilled or exceeded. Whereas according to Nurachmah (2005), patient satisfaction is defined as postconsumption evaluation that a selected product at least meets or exceeds expectations.

According to Lukman (2003: 119), "Consumers' satisfaction is defined as the level of one's feelings after comparing the performance (results) felt to his expectations". Furthermore, Gasperz in Lukman (2003: 123), states that "basically customers' satisfaction can be defined simply as a situation where the needs, desires, expectations of customers can be fulfilled through the products consumed".

Moreover, Endang (in Mamik, 2010: 110), says that patients' satisfaction is an evaluation or assessment after using a service, that the service chosen at least meets or exceeds expectations. Whereas Pohan (2007: 145) states that patients' satisfaction refers to the level of patients' feeling that arises as a result of the performance of health services obtained, after the patient compares to what he expects.

According to Budiastuti (in Nooria; 2008: 6), factors that influence patients' satisfaction are:

a. The quality of the product or service. Patients will be satisfied if the results of their evaluation indicate that the product or service used has high quality. The patient's perception of the quality of 
the product or service is affected by the reality of the quality of the product or service and the company communication, in this case, the hospital in advertising its place.

b. The service quality. Patients will feel satisfied if they get good or appropriate service.

c. Emotional factors. Patients feel proud, satisfied and amazed at hospitals that are considered as "expensive hospitals".

d. Price. The more expensive the price of treatment, the greater expectations the patient has. On the other hand, the hospitals that have equal quality but cheaper, give higher values to patients.

e. Costs. Patients who do not need to spend additional costs or to waste time to get services tend to be satisfied with these services.

Patients' satisfaction is generally interpreted as a comparison between services or results received to patients' expectations. If the health service received by the patient does not meet the expectation, it menas that the patient is not satisfied. On the contrary, if the health service received by the patient matches or exceeds the patients' expectations, the patients will feel satisfied with the health service they receive.

Based on some definitions above, it can be concluded that patients' satisfaction is the subjective value of patients for the services provided after comparing the results of services provided to the expectations. Patients will feel satisfied if the service provided matches the patients' expectations or even more than what the patients expect. According to Abdullah (2006: 50), indicators of customers' satisfaction (patients) are Hospitality to Customers, Personal Attention, Level of Knowledge in Providing Services, Availability of Service Programs, Service Accuracy, Service Speed, Ease of Obtaining Services, Positive Feedback.

\section{Competence}

Competence intended in this study untilizes the indicators of the employees' intellectual ability and physical abilities in demonstrating skills or knowledge characterized by professionalism in a particular field as the most important and superior in the field. According to Wibowo (2007: 112), competence is an ability to carry out a work or task based on knowledge and skills and supported by the work attitude demanded by the job. Whereas according to Armstrong (in Dharma, 2004: 86), competence refers to the behavioral dimensions of a role or behavior required by someone to be able to perform their work satisfactorily. According to Mangkunegara (2007: 88), competency in human resources is related to knowledge, skills, abilities, and personal characteristics that directly affect its performance. Competence refers to an ability to perform a job or task based on skills, knowledge and supports from the work attitude demanded by the worker (Wibowo, 2011: 324).

In addition, competence is the mastery of tasks, skills, attitudes, and appreciation needed to support success. This shows that competence includes the tasks, attitude skills and appreciation that must be possessed (Mulyasa, 2004: 38). Meanwhile, Edy Sutrisno (2009: 221) defines competence as a basic characteristic of a person that allows him to provide superior performance in a particular job, role, or situation. He adds that skills are things that people can do well while knowledge is what someone knows about a topic. Furthermore, he explains that competence is a complaint of knowledge, skills, values, and attitudes reflected in the thinking and acting habit. If competency is interpreted the same as ability, it is implied that knowledge recognizes the purpose of work, in carrying out accurate tips to perform the right and good work (Edy Sutrisno, 2009: 222).

Then, competence refers to knowledge, skills, and abilities that are mastered by someone which has become a part of him. As a result, he can do cognitive, affective, and psychomotor behaviors as well as possible (Edy Sutrisno, 2010: 203). Hasibuan (2003: 87) asserts that competence is the basic foundation of people's characteristics and indicates how to behave or think, equate situations, and support for a long period of time. Rosidah (2009: 11) adds that competence is a basic characteristic of a person that allows employees to produce superior performance in their work. Finally, competence is the characteristic that underlies a person with regard to the effectiveness of individual performance in his work. It is also defined as the basic characteristics of individuals who have a causal relationship or a cause and effect with the criteria used as reference (Moeheriono, 2009: 3). Meanwhile, in the Law No.13 / 2003 concerning Manpower Article 1 paragraph 10, it is stated that competency is the work ability of each individual which includes aspects of knowledge, skills, and work attitudes that are in accordance with established standards. 


\section{Doctors}

According to Astuti (2009: 52), doctors are people who have the authority and permission to accomplish health services, specifically examining and curing diseases and performed according to law in health services. Alamsyah and Muliawati (2013: 48) add that the competencies that must be achieved by a doctor include seven areas of competence or main competencies; they are:

1. Effective communication skills.

2. Basic clinical skills.

3. Skills to apply the basics of biomedical sciences, clinical sciences, behavioral sciences and epidemiology in medical practice.

4. Health management skills in individuals, families or communities in a comprehensive, holistic, continuous, coordinated and collaborative manner in the context of Primary Health Services.

5. Utilizing, assessing critically and managing information.

6. Self-awareness and self-development / lifelong learning.

7. Upholding ethics, morals and professionalism in practice.

\section{Nurses}

Nurses are people who graduated from education both in the country and abroad in accordance with the laws and regulations (Permenkes, 2010). According to Rendy (2013: 79), nurses have duties, roles and functions for the community so that their position is highly valued. Several duties of nurses are Care Giver, Client Advocate, Counselor, Educator, Coordinator, Collaborator, Consultant and Change Agent. The functions of Nurses are: 1) Independent Function, 2) Dependent Function, 3) Interdependent Function. This function refers to a "team work", tend to be interdependent in both nursing and health.

\section{Midwifes}

Midwives are those who have attended and completed the education of midwifery approved by the government and they have passed an examination in accordance with the requirements applied, recorded (registered), and given legal permission to carry out the practice (Nazriah, 2009). According to Estiwidani.D, et al (2008), the role and function of midwives in midwifery services are as implementers, managers, educators, and researchers. Meanwhile, the responsibilities of midwives include counseling services, normal midwifery services, abnormal midwifery services, midwifery services for children, family planning services, and public health services. The complexity of the roles, functions, and responsibilities of midwifes in carrying out their duties provides the best midwifery services and professionals to the community so that for the success to achieve these goals requires a strong foundation in the form of competency midwives.

\section{The Employees' Competency}

The employees' competency is required by every organization, especially to improve job performance. According to Prihadi (2004: 57), the benefits of competence are:

1. Predictors of work success. An accurate competency model will be able to exactly determine what knowledge and skills are needed to be successful in a job. If a position holder is able to have the competencies required in his position, it can be predicted that he will be successful.

2. Recruiting reliable employees. If the competencies required for a particular position have been successfully determined, these competencies can be easily used as a basic criterion in recruiting new employees.

3. The basic assessment and development of employees. Identifying accurate job competencies can also be used to measure someone's ability. Thus, based on this competency system, it can be observed whether someone has developed his competency with training and guidance or it needs to be transferred to another part.

Hence, it can be concluded that competence can also be interpreted as the ability and willingness to perform work with effective and efficient performance to achieve goals (Robbins, 2007: 53-55). The indicators of competency consists of two dimensions: (1) intellectual abilities and (2) physical abilities.

\section{Infrastructure}


According to Rendy (2013: 72), medical facilities are anything that can be used as a tool to achieve the purpose or goal; tool; media, which can be used. Meanwhile, according to Sulastiyono (2006: 86), there are three indicators of Facilities/ Infrastructure: (1) Patients' evaluation of the completeness of the service facilities/ infrastructure, (2) Patients evaluation of facilities/ infrastructure supporting the services, (3) Patients' evaluation of the cleanliness of the service facilities/ infrastructure.

According to the Indonesian Ministry of Health (2003), the standards of infrastructure required in the development of Inpatient Health Centers are:

1. Adequate outpatient rooms (comfortable, spacious and separate between children, women and men to maintain privacy)

2. Operation room and post-operation room

3. Delivery room (and nursing room as well as recovery room)

4. Rooms for nurse on guard

5. Linen and laundry rooms

Meanwhile, the standards of medical equipments needed in the development of inpatient health centers are as follow:

1. Limited operating equipments

2. Pathological obstetric equipment, vasectomy and tubectomy equipments

3. Resuscitation equipments

4. A minimum of 10 beds with care equipments

5. Communication and Transportation Tools

6. Medium-distance telephones or radio communication

7. One ambulance (minimum)

The above standards are the minimum requirements since to improve the service quality, innovations from the head of Puskesmas is necessary, related to medicine, medical supports, medical care protection with upto-date references, as well as regular medical reviews and non-medical and other activities.

Based on the Minimum Service Standards in Health Sector in Kabupaten/ City (the Ministry of Health, 2003), the coverage of inpatient is the coverage of new inpatient visits in private and government health care facilities in a working area at a certain period of time. The number of new inpatient visits refers to the number of new inpatient visits that gets health services at the General Poly, both inside and outside the building in one working area at a certain period of time and the denominator is the number of residents in one working area at the same period of time. To achieve the goal of service coverage, several steps of the activities carried out include:

1. Collecting the data of Population, health facilities, and visits to health facilities

2. Increasing health infrastructure and facilities

3. Analysis of service needs

4. Counseling

5. Human Resources Training

6. Recording and reporting

\section{Accessibility}

Sutantono (2004: 1) states that accessibility refers to the right to access which is a basic travel needs service. In this case accessibility must be provided by the government regardless of the use of the transportation modes provided by the community. After that, Susantono (2004: 24) adds that accessibility is a potential measure or people's convininece to achieve goals on a trip. The characteristics of the transportation system are determined by accessibility. Accessibility gives influence to several locations of activities or land use. The location of activities also has an influence on travel patterns for carrying out daily activities. This travel pattern then affects the transportation network and will also influence the overall transportation system. Thus, location is a crucial factor that can influence consumer purchasing decisions. The right location will make a restaurant more successful than other less strategically located restaurants, even though the restaurant sells the same food and also has a sales clerk who has the same quality and quantity. 
Moreover, Swasta and Irawan (2003) assert that location refers to the location or retail store in a strategic area so that it can maximize profits. Location influences strategic dimensions, such as flexibility, competitive positioning, demand management, and focus strategic (Tjiptono and Chandra, 2005).

The accessibility of a location is a measure of the extent to which a business location can be reached or passed while competitive positioning is the methods used to enable the companies develop their relative position compared to competitors. If the company succeeds in obtaining and maintaining a strategic location, it can be an effective obstacle for competitors to gain access to markets (Tjiptono and Chandra, 2005). Whereas Lupiyoadi (2001: 32) defines location as a place where the company must be based in conducting operations. In this case, three types of interactions that affect location are:

1. Customers visit the service providers (companies), if so, the location becomes very important. The company should choose a place close to the customers so that it is easily accessible; in other words must be strategic;

2. Service providers come to customers, in this case, the location is not too important but what must be considered is the delivery of services must remain high quality;

3. Service providers and customers do not meet in person, which means that service providers and customers interact through certain facilities such as telephones, computers and letters.

Careful considerations in determining locations according to Tjiptono (2005) include factors such as:

1. Access; for example, a location that is easily passed by or easily accessible by public transportation facilities;

2. Visibility; for example, the location can be seen clearly from the edge of the road;

3. A large and safe parking lot;

4. Expansion, which is the availability of a sufficiently large place for business expansion in the future;

5. Environment, that is the surrounding area that supports the services offered.

From some understandings of accessibility stated above, it can be concluded that accessibility in the hospital environment is shown from the patients' convenience in obtaining treatment. This can be seen from the services provided and public facilities available in it. According to (Pudjiantoro, 2008), there are two indicators of accessibility, namely (1) Accessibility of services, (2) accessibility of facilities.

\section{Previous Studies}

Table 2. Previous studies on Competence, Infrastructure, Accessibility and Patients' Satisfaction.

\begin{tabular}{|c|c|c|c|}
\hline $\mathrm{NO}$ & Researcher (Years) & RESEARCH VARIABLE & RESEARCH RESULT \\
\hline 1 & $\begin{array}{l}\text { Faigah A. Badjamal } \\
(2014)\end{array}$ & $\begin{array}{l}\text { The Effect of Competence } \\
\text { and Facilities on Class } 3 \\
\text { Patients Satisfaction at } \\
\text { RUSD Palu. }\end{array}$ & $\begin{array}{l}\text { The competence Influences } \\
\text { Patients' Satisfaction }\end{array}$ \\
\hline 2 & $\begin{array}{l}\text { Ida Yunari Ristiani } \\
\text { (2017) }\end{array}$ & $\begin{array}{l}\text { The Effect of Infrastructure } \\
\text { and Service Quality on } \\
\text { Patients' Satisfaction (Study } \\
\text { on Outpatient Patients in the } \\
\text { Ipdn Polyclinic Unit in } \\
\text { Jatinangor) }\end{array}$ & $\begin{array}{l}\text { There is a relationship } \\
\text { between facilities and } \\
\text { patients' satisfaction. }\end{array}$ \\
\hline 3 & $\begin{array}{l}\text { Dela } \\
\text { Purwandani,Cicih } \\
\text { Sutarsih, Sururi } \\
(2016)\end{array}$ & $\begin{array}{l}\text { The effect of the quality of } \\
\text { facilities and infrastructure } \\
\text { service on students' } \\
\text { satisfaction in the faculty of } \\
\text { technology and vocational } \\
\text { education Universitas } \\
\text { Pendidikan Indonesia }\end{array}$ & $\begin{array}{l}\text { There is a positive and } \\
\text { significant } \\
\text { between the Quality of } \\
\text { Facilities and Infrastructure } \\
\text { Service on Students' } \\
\text { Satisfaction at the Faculty of } \\
\text { technology and Vocational } \\
\text { Education Universitas } \\
\text { Pendidikan Indonesia }\end{array}$ \\
\hline 4 & $\begin{array}{l}\text { Rita Fahdila } \\
\text { Sumantri, (2012) }\end{array}$ & $\begin{array}{lr}\text { Kompetensi } & \text { pengelolaan } \\
\text { pembelajaran, } & \text { Kecerdasan }\end{array}$ & $\begin{array}{lr}\text { Learning } & \text { management } \\
\text { competencies } & \text { directly }\end{array}$ \\
\hline
\end{tabular}




\begin{tabular}{|c|c|c|c|}
\hline & & $\begin{array}{l}\text { interpersonal, komitmen, dan } \\
\text { Kepuasan kerja guru smk } \\
\text { Learning management } \\
\text { competencies, interpersonal } \\
\text { intelligence, commitment, } \\
\text { and job satisfaction for } \\
\text { vocational high school } \\
\text { teachers }\end{array}$ & $\begin{array}{lll}\text { influence } & \text { teachers' job } \\
\text { satisfaction } & & \end{array}$ \\
\hline 5 & $\begin{array}{l}\text { Alicia, Yanwir } \\
\text { Kamal, (2013) }\end{array}$ & $\begin{array}{l}\text { Factors Associated with } \\
\text { Social ASKES Participants' } \\
\text { Satisfaction on Family } \\
\text { Physician Services at PT. } \\
\text { ASKES (Persero) in } \\
\text { Kabupaten Kuantan Singingi }\end{array}$ & $\begin{array}{l}\text { There is a relationship } \\
\text { between facilities and } \\
\text { infrastructure at family doctor } \\
\text { and satisfaction of Social } \\
\text { Askes participants }\end{array}$ \\
\hline 6 & $\begin{array}{l}\text { Fardiansyah Ahmad, } \\
\text { Irmayani, Adriani } \\
\text { Kadir,(2013) }\end{array}$ & $\begin{array}{l}\text { The influence of facilities and } \\
\text { infrastructure, patient } \\
\text { admission procedures, nurse } \\
\text { services on the level of } \\
\text { patients' satisfaction in the } \\
\text { inpatient room of Makassar's } \\
\text { regional public hospital } \\
\text { (RSUD). }\end{array}$ & $\begin{array}{l}\text { There are influences of } \\
\text { infrastructure, patient } \\
\text { admission procedures, and } \\
\text { nurse services on patients' } \\
\text { satisfaction }\end{array}$ \\
\hline 7 & $\begin{array}{l}\text { Afifah Audistiana, } \\
\text { Muslichah Erma } \\
\text { Widiana, Bramastyo } \\
\text { Kusumo } \\
\text { Negoro,(2017) }\end{array}$ & $\begin{array}{l}\text { The effect of accessibility, } \\
\text { facilities and customers' } \\
\text { satisfaction on customer } \\
\text { loyalty in Sidoarjo fishing } \\
\text { delta. }\end{array}$ & $\begin{array}{l}\text { The variables of accessibility, } \\
\text { facilities and customers' } \\
\text { satisfaction have a significant } \\
\text { effect simultaneously and } \\
\text { partially towards customers' } \\
\text { loyalty in Sidoarjo fishing } \\
\text { delta. }\end{array}$ \\
\hline 8 & $\begin{array}{l}\text { Metta Primaningtyas } \\
\text { (2012) }\end{array}$ & $\begin{array}{l}\text { The effect of accessibility, } \\
\text { physical attributes, } \\
\text { environment health and } \\
\text { public facilities for } \\
\text { satisfaction to settle (a case } \\
\text { study at PT. Armada Hada } \\
\text { Graha Magelang) }\end{array}$ & $\begin{array}{l}\text { Empirically, accessibility, } \\
\text { physical factors, environment } \\
\text { health and public facilities are } \\
\text { factors that influence the } \\
\text { satisfaction of living in } \\
\text { property developed by PT. } \\
\text { Armada Hada Graha } \\
\text { Magelang }\end{array}$ \\
\hline 9 & $\begin{array}{l}\text { Mira Taufik dkk, } \\
(2015)\end{array}$ & $\begin{array}{l}\text { The Comparison of Patients' } \\
\text { Satisfaction and Health } \\
\text { Services according to } \\
\text { Regional Accessibility } \\
\text { (Subdistrict Case) }\end{array}$ & $\begin{array}{l}\text { Patients' satisfaction is not } \\
\text { related to regional } \\
\text { accessibility }\end{array}$ \\
\hline 10 & $\begin{array}{l}\text { Seoyoung Lee, RN, } \\
\text { MSN,Eun-Kyung } \\
\text { Kim, RN, } \\
\text { PhD,(2017) }\end{array}$ & $\begin{array}{l}\text { The Effects of Korean } \\
\text { Medical Service Quality and } \\
\text { Satisfaction on Revisit } \\
\text { Intention of the United Arab } \\
\text { Emirates Government } \\
\text { Sponsored Patients }\end{array}$ & $\begin{array}{l}\text { There is a basic need that } \\
\text { must be given by the hospital } \\
\text { to patients' satisfaction, but it } \\
\text { is also important for the } \\
\text { government of Saudi Arabia } \\
\text { to provide assistance and } \\
\text { support for patients. }\end{array}$ \\
\hline 11 & $\begin{array}{l}\text { Karami Kabir Nahid, } \\
\text { Lotfi Mojgan, } \\
\text { Tayebeh } \\
\text { hasantehran, pashaee } \\
\text { sabet }\end{array}$ & $\begin{array}{l}\text { The effective factors on } \\
\text { satisfaction from the view } \\
\text { point of patients at the } \\
\text { emergencyWards in Tabriz } \\
\text { Emam and Sina hospitals, }\end{array}$ & $\begin{array}{l}\text { The findings of this study } \\
\text { indicate that the percentage of } \\
\text { physical environmental } \\
\text { factors is } 65 / 93 \% \text {, for human } \\
\text { resources is } 67 / 90 \% \text {, for }\end{array}$ \\
\hline
\end{tabular}




\begin{tabular}{|c|c|c|c|}
\hline & Fatemeh,(2012) & (2010) & $\begin{array}{l}\text { protective factors is } 68 / 10 \% \text {, } \\
\text { and for management factors } \\
\text { is around } 46 / 93 \% \text {. Those are } \\
\text { factors that are considered } \\
\text { effective in patients' } \\
\text { satisfaction. And also the } \\
\text { results of this study indicate } \\
\text { that attitudes and behavior of } \\
\text { nurses and others also have } \\
\text { an influence on patients' } \\
\text { satisfaction. }\end{array}$ \\
\hline 12 & $\begin{array}{l}\text { Dr. Abdalelah } \\
\text { Saifuddin Saaty, } \\
\text { and Dr. Zaid Ahmad } \\
\text { Ansari. (2014) }\end{array}$ & $\begin{array}{l}\text { Patient's Satisfaction from the } \\
\text { Infrastructure Facilities of the } \\
\text { Government Hospitals in } \\
\text { Saudi Arabia }\end{array}$ & $\begin{array}{l}\text { The results of this study } \\
\text { reveal that patients are } \\
\text { dissatisfied with the } \\
\text { infrastructure } \\
\text { available at Saudi Arabian } \\
\text { hospitals. }\end{array}$ \\
\hline 13 & $\begin{array}{l}\text { Sriharni } \\
\text { Patandianan, Tri } \\
\text { Ratnawati, Sigit } \\
\text { Sardjono, (2018) }\end{array}$ & 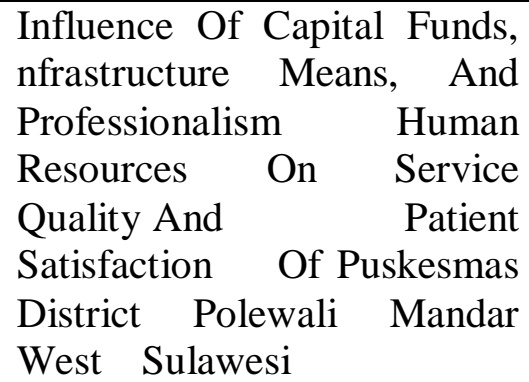 & $\begin{array}{l}\text { The results of this study } \\
\text { indicate that Puskesmas } \\
\text { capitation fund has an } \\
\text { influence on the quality of } \\
\text { service and satisfaction of } \\
\text { BPJS patients registered at } \\
\text { Puskesmas Polewali Mandar, } \\
\text { West Sulawesi. }\end{array}$ \\
\hline 14 & $\begin{array}{l}\text { Jung-Won Ahn, } \\
\mathrm{PhD},(2017)\end{array}$ & $\begin{array}{l}\text { Structural Equation Modeling } \\
\text { of Cultural Competence of } \\
\text { Nurses Caring for Foreign } \\
\text { Patients }\end{array}$ & $\begin{array}{l}\text { Nurses' competency can be } \\
\text { improved by providing } \\
\text { multicultural nurse education, } \\
\text { increasing experience both } \\
\text { directly and indirectly, and } \\
\text { promoting sharing in solving } \\
\text { problems related to nursing } \\
\text { problems. }\end{array}$ \\
\hline 15 & $\begin{array}{l}\text { Nayeon Shin, Jummi } \\
\text { Park, (2018) }\end{array}$ & $\begin{array}{l}\text { The Effect of Intentional } \\
\text { Nursing Round s Based on } \\
\text { the Care Model on Patients' } \\
\text { Perceived Nursing Quality } \\
\text { and their Satisfaction with } \\
\text { Nursing } \\
\text { Service s }\end{array}$ & $\begin{array}{l}\text { This study shows that nursing } \\
\text { rotation based on nursing } \\
\text { models is considered } \\
\text { effective in the perspective of } \\
\text { the improvement of nurses' } \\
\text { quality and patients' } \\
\text { satisfaction. }\end{array}$ \\
\hline 16 & $\begin{array}{l}\text { Tanzer Korkmaz, } \\
\text { Burcin Balaban, } \\
\text { Husnu Onder, , } \\
\text { Fusun Saricil, (2016) }\end{array}$ & $\begin{array}{l}\text { The effect of patients' } \\
\text { qualifications and number of } \\
\text { patients' companions on } \\
\text { patients' satisfaction }\end{array}$ & $\begin{array}{l}\text { The results of this study } \\
\text { demonstrate that the } \\
\text { satisfaction of patient } \\
\text { companion increases if the } \\
\text { patient is a woman and is } \\
\text { hospitalized. The level of } \\
\text { education increases the level } \\
\text { of patients' satisfaction. }\end{array}$ \\
\hline
\end{tabular}

\section{Conceptual Framework}

The conceptual framework in this study can be seen in the following figure: 


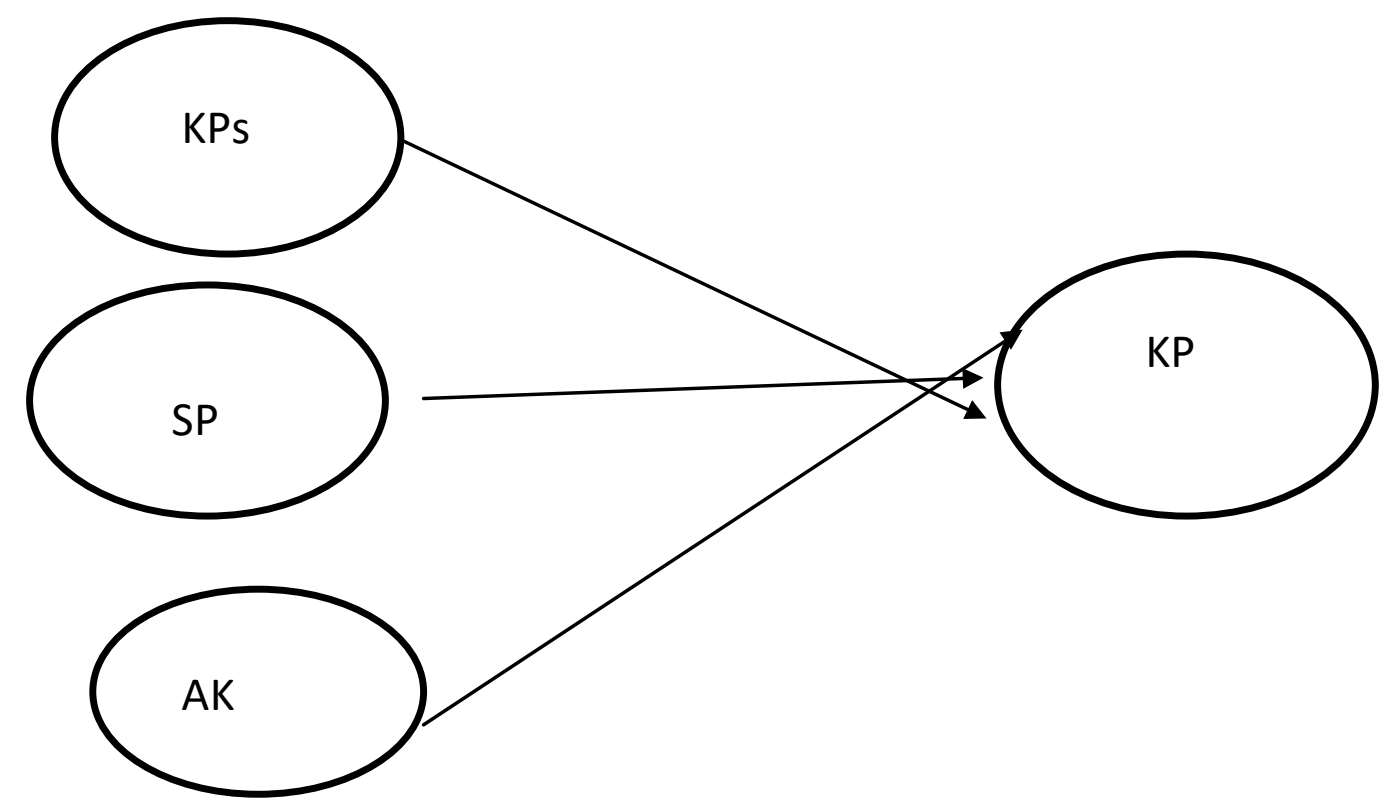

Figure 1. Conceptual Framework

Note :

KPs $=$ Competence

$\mathrm{SP} \quad=$ Infrastructure

$\mathrm{AK} \quad=$ Accessibility

$\mathrm{KP} \quad=$ Patient Satisfaction

\section{Research Hypotheses}

Referring to the conceptual framework above, this research has 3 (three) hypotheses:

1. Competence has a positive and significant effect on patients' satisfaction

2. Infrastructure has a positive and significant effect on patients' satisfaction.

3. Accessibility has a positive and significant effect on patients' satisfaction

\section{Research Methods}

The object this study was Puskesmas at Kabupaten Indragiri Hulu, which were all Puskesmas in Kabupaten Indragiri Hulu. The population in this study were all patients who visited a health center in Kabupaten Indragiri Hulu. However, the researchers limited the population objects to 3 Puskesmas because they were categorized into excellent, good and moderate. The three Puskesmas were Kota Kampung Besar, Sipayung, Pekan Heran, with a total population of 165,435 people. The samples of this study were chosen by utilizing a statistical approach developed by Slovin and 100 respondents were taken as the samples by using the proportional random sampling method. The data were collected by distributing questionnaire, which was a closed questionnaire. After that, the data were measured by using Likert scale. Then, the data were analyzed by implementing SEM (Structural Equation Modeling) analysis which was operated through SmartPLS 3 Application.

\section{Results and Discussion Validity Testing}




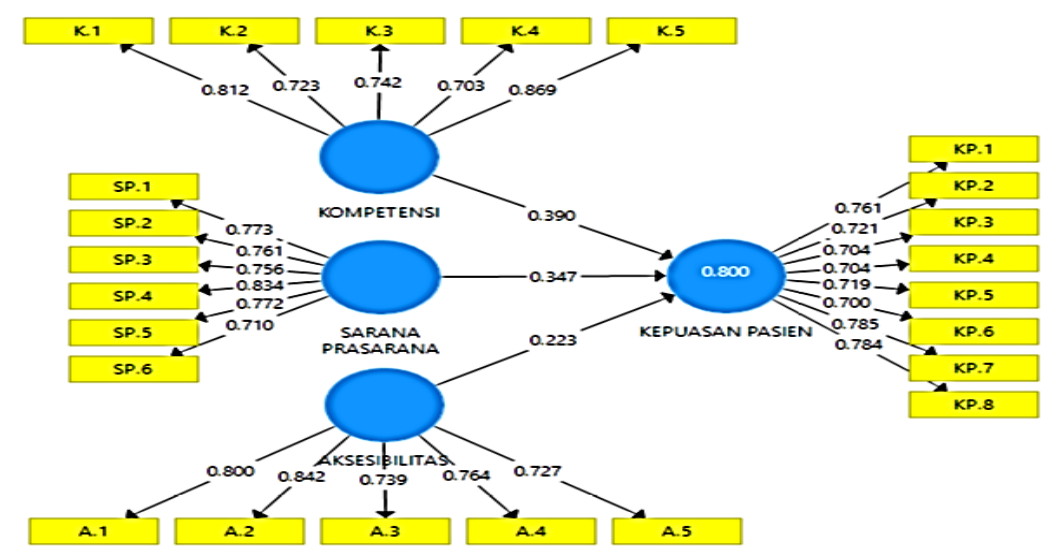

Figure 2: Validity Test

Sources: Processed PLS Data

Figure 2 shows that the calculated $\mathrm{R}$ value is greater than 0.7 . It can be concluded that all 24 questions are valid.

\section{Reliability Testing}

Table 3. Reliability Test.

\begin{tabular}{|l|c|c|c|c|c|c|}
\hline \multicolumn{1}{|c|}{ Variables } & $\begin{array}{c}\text { No of } \\
\text { Questions }\end{array}$ & $\begin{array}{c}\text { The Value } \\
\text { of } \\
\text { Cronbach's } \\
\text { Alpha }\end{array}$ & $\begin{array}{c}\text { The } \\
\text { Value of } \\
\text { rho_A }\end{array}$ & $\begin{array}{c}\text { The Value } \\
\text { of } \\
\text { Composite } \\
\text { Reliability }\end{array}$ & $\begin{array}{c}\text { Minimum } \\
\text { Score }\end{array}$ & Remarks \\
\hline Competence & 5 & 0,829 & 0,842 & 0,880 & 0,7 & Reliable \\
\hline $\begin{array}{l}\text { Facilities and } \\
\text { Infrastructure }\end{array}$ & 6 & 0,879 & 0,867 & 0,896 & 0,7 & Reliable \\
\hline Accessibility & 5 & 0,834 & 0,850 & 0,883 & 0,7 & Reliable \\
\hline $\begin{array}{l}\text { Patients' } \\
\text { Satisfaction }\end{array}$ & 8 & 0,879 & 0,882 & 0,904 & 0,7 & Reliable \\
\hline
\end{tabular}

Sources: Processed PLS Data

Table 3 demonstrates that all values of Cronbach's Alpha, rho_A and Composite Reliability are greater than 0.7. It can be concluded that all variables are reliable.

Hypotheses Testing: Hypotheses Testing in this study is illustrated in Figure 2.

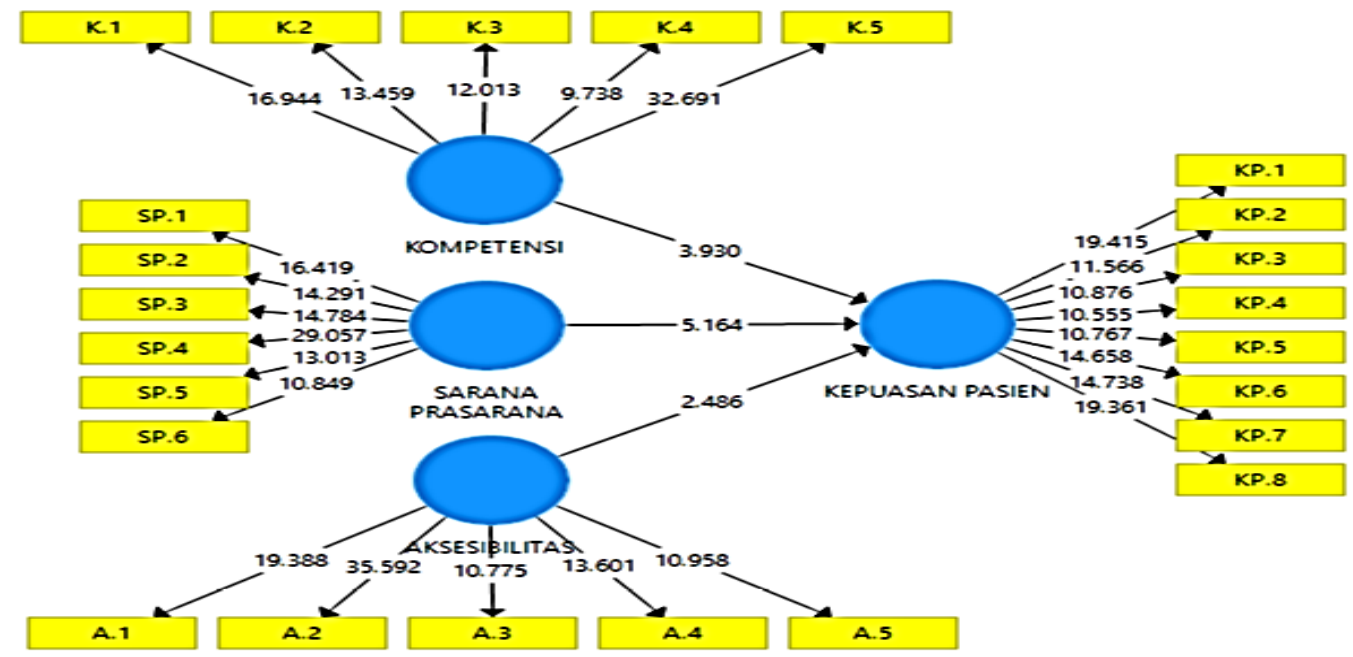

Figure 2. Hypotheses Testing 
The value of t-table is 1.984 . The statistical results of the influence of competencies, infrastructure and accessibility to patients' satisfaction are as follows:

\section{H1. The Effect of Competence on Patients' Satisfaction.}

The result of structural equations reveals that the variable of Competence on Patients Satisfaction obtained the value of $\mathrm{t}$-Count $>\mathrm{t}$-Table that was 3,930 > 1,984. It can be concluded that competence has a positive and significant effect on patients' satisfaction. Thus, $\mathrm{H}_{1}$ was accepting and $\mathrm{H}_{0}$ was rejected.

The results of this study are supported by the results of previous studies conducted by Rita Fahdila Sumantri (2012), Faigah A. Badjamal (2014), Rahma Indrawati (2106), Karami Kabir Nahid et al. (2010). Those studies found that competence affected patients' satisfaction. Thus, it can be concluded that the quality of medical and non-medical staffs will directly affect patients' satisfaction.

\section{H2. The Effect of Infrastructure on Patients' Satisfaction}

The result of structural equation for hypothesis 2 shows that the value of variable of infrastructure on patients' satisfaction was t-count value $5.164>\mathrm{t}$-table 1.984. It can be concluded that infrastructure facilities have a positive and significant effect on patients' satisfaction. Thus, $\mathrm{H}_{2}$ was accepted and $\mathrm{H}_{0}$ was rejected.

The results of this study are supported by the results of previous studies conducted by Dela Purwandani, Cicih Sutarsih, Sururi (2016), Alicia, Yanwir Kamal (2013) Ida Yunari Ristiani (2017) Fardiansyah Ahmad, Irmayani, Adriani Kadir (2013). They revealed that infrastructure had a positive and significant effect on patients' satisfaction. Hence, it can be concluded that puskesmas will provide patients' satisfaction because of adequate infrastructure.

\section{H3. The Effect of Accessibility on Patients' Satisfaction.}

Based on the result of structural equation for hypothesis 3, it was found that the value of Accessibility on Patients' Satisfaction with the value of t-Count $>\mathrm{t}$-Table was $2.496>1.984$. It can be concluded that accessibility has a positive and significant effect on patients' satisfaction. Thus, $\mathrm{H}_{3}$ was accepted and $\mathrm{H}_{0}$ was rejected.

The results of this study are in line with the results of previous studies conducted by Afifah Audistiana, Muslichah Erma Widiana, Bramastyo Kusumo Negoro (2017), Metta Primaningtyas (2012) Christian Cussoy, Inge Puspa Puspita, Agung Hariyanto (2017), Ni Kadek Suari Suma Dewi (2014). They found that accessibility had a positive effect on patient satisfaction. In short, it can be concluded that the smooth access to puskesmas increases patients' satisfaction.

\section{Conclusion and Recomendation \\ Conclusion}

Based on the results of the research, it can be concluded that competence has a positive and significant effect on patients' satisfaction. Then, the facilities positively and significantly affect patients' satisfaction. At last, accessibility also has a positive and significant effect on patients' satisfaction.

\section{Recomendation}

1. From the results of the study, it is concluded that infrastructure has a greater influence on patients' satisfaction compared to competence and accessibility. It implies that to increase the patients' satisfaction at Puskesmas in Kabupaten Indragiri Hulu, it is focused more on increasing its infrastructure and facilities. The statements to be considered for the improvement of Infrastructure and facilities are about increasing the number of medical equipment, supporting facilities and the health center rooms cleanliness.

2. Based on the result on competency, it is expected that there is an improvement on the competency of medical and non-medical staffs in order to be more proactive in increasing the patients' satisfaction at Puskesmas in Kabupaten Indragiri Hulu.

3. Based on the result on accessibility, it is expected that the government give more attention to prepare good access from puskesmas to referral hospitals to facilitate quick response services in increasing patients satisfaction. 
4. The contribution of patients' satisfaction is influenced by other variables including professional medical staffs, medical staffs' experience, staffs'/ employees' discipline, and Standard Operating System (SOP). Then it is necessary to do further research to find out the variables that are able to improve the quality of services provided to patients at Puskesmas.

\section{References}

[1] A., \& Kamal, Y. (2017). Faktor- faktor yang Berhubungan dengan Kepuasan Peserta ASKES Sosial dalam Pelayanan Dokter Keluarga PT. ASKES (Persero). Jurnal Kesehatan Komunitas, 2(2), 100. https://doi.org/10.25311/jkk.vol2.iss2.53

[2] Abdalelah Saifuddin Saaty, Z. A. A. (2016). Patient's Satisfaction from the Infrastructure Facilities of the Government Hospitals in Saudi Arabia, 2(6), 531-539.

[3] Ahmad, F., \& Kadir, A. (2013). DI RUANG RAWAT INAP RUMAH SAKIT UMUM DAERAH ( RSUD ) DAYA MAKASSAR, 2, 1-8.

[4] Ahmad Susanto, Teori Belajar Dan Pembelajaran Di Sekolah Dasar,(Jakarta: Kencana Prenada Media Group, 2013). (2015). No Title Preparation of Activated Carbon from Furfural Residues by Phosporic Acid Activation. Biomass Chem Eng, 49(23-6), 22-23.

[5] Ahn, J. W. (2017). Structural Equation Modeling of Cultural Competence of Nurses Caring for Foreign Patients. Asian Nursing Research, 11(1), 65-73. https://doi.org/10.1016/j.anr.2017.03.001

[6] Afifah Audistiana, Muslichah Erma Widiana, Bramastyo Kusumo Negoro (2017) Pengaruh Aksesibilitas, Fasilitas Dan Kepuasan Pelanggan Terhadap Loyalitas Pelanggan Di Delta Fishing Sidoarjo, Jurnal Manajemen Branchmark Vol 3 Issue 3, 2017.

[7] Armstrong, Michail. Manajemen SDM. Terjemahan: Sofyan Cikmar dan Haryanto. Jakarta: PT. Media Kompetindo.1999

[8] A.A. Anwar Prabu Mangkunegara,2007, ManajemenSumber Daya Manusia,Cetakan Ke Tujuh PT.Remaja Rosdakarya, Bandung

[9] Astuti, Endang Kusuma, 2009, Perjanjian Terapeutik Dalam Upaya Pelayanan Medis di Rumah Sakit. Bandung: Citra Aditya Bakti.

[10] Abdullah. Laporan penelitian : Hubungan Antara Kepuasan, Kepercayaan, Komitmen terhadap Kesetiaan Para Pelanggan Servis Mobil Toyota di ASTRIDO Toyota Pondok Indah Jakarta Selatan. Jakarta : Program Pasca Sarjana UPDM(B). 2006

[11] Alamsyah D, Ratna Muliawati. Pilar Dasar Ilmu Kesehatan Masyarakat. Yogyakarta: Nuha Medika; 2013.

[12] Audistiana, A. (2017). Pengaruh Aksesibilitas Fasilitas dan Kepuasan Pelanggan Terhadap Loyalitas Pelanggan di Delta Fishing Sidoarjo, 3(3), 237-250.

[13] Badjamal, F. A. (2014). Pengaruh Kompotensi Dan Fasilitas Terhadap Kepuasaan Pasien Rawat Inap Kelas 3 Pada Rsud Palu. E-Jurnal Katalogis, 2.

[14] Basu Swastha dan Irawan. 2003. "Manajemen Pemasaran Modern”. (Edisi kedua). Cetakan ke sebelas. Yogyakarta : Liberty Offset.

[15] Christy Cussoy, Inge Puspa Puspita, Agung Hariyanto(2107)Analisis Pengaruh Accessibility Dan Security Terhadap Customer Satisfaction Dan Customer Loyalty Nasabah Klikbca.

[16] Dinawan, M. R. (2010). Jurnal sains pemasaran indonesia. Sains Pemasaran Indonesia, VIII (1), 83106. Retrieved from https://ejournal.undip.ac.id/index.php/jspi/article/download/14111/10956

[17] Dela Purwandani, Cicih Sutarsih, Sururi (2016) Pengaruh Mutu Layanan Sarana Dan Prasarana Terhadap Kepuasan Mahasiswa Di Fakultas Pendidikan Teknologi Dan Kejuruan Universitas Pendidikan Indonesia. Jurnal ADPEND.

[18] Darlius, (2015). Pengaruh Kompetensi Dokter, Pelayanan Dan Fasilitas Terhadap Kepuasan Pasien Medical Chek Up Rumah Sakit Siloam Lippo Cikarang Bekasi.

[19] Estiwidani, dkk.2008. Konsep Kebidanan. Yogyakarta:Penerbit Fitramaya.

[20] Faigah A. Badjamal (2014), Pengaruh Kompotensi Dan Fasilitas Terhadap Kepuasaan Pasien Rawat Inap Kelas 3 Pada Rsud Palu. 201201 e-Jurnal Katalogis, Volume 2 Nomor 7, Juli 2014 hlm 200ISSN: 2302-2019.

[21] Fardiansyah Ahmad, Irmayani, Adriani Kadir (2013) Pengaruh Sarana Prasarana, Prosedur Penerimaan Pasien, Pelayanan Perawat Terhadap Tingkat Kepuasan Pasien Di Ruang Rawat Inap 
Rumah Sakit Umum Daerah (Rsud) Daya Makassar. Volume 2 Nomor 1 Tahun 2013, ISSN : 23021721.

[22] Gerson, Richard. F.2004 Mengukur Kepuasan Pelanggan, PPM, Jakarta.

[23] Hasibuan, Malayu. 2008.Manajemen Dasar, Pengertian, Dan Masalah. Jakarta:PT Bumi Aksara

[24] Hafizurrachman. (2004). Pengukuran Kepuasan Suatu Institusi Kesehatan.Majalah Kedokteran Indonesia. Volume 54. nomor 7. 283 - 288.

[25] Ida Yunari Ristiani (2017) Pengaruh Sarana Prasarana Dan Kualitas Pelayanan Terhadap Kepuasan Pasien (Studi Pada Pasien Rawat Jalan Unit Poliklinik Ipdn Jatinangor) Coopetition Vol VIII, Nomor 2, November 2017, $155-166$.

[26] Korkmaz, T., Balaban, B., Onder, H., \& Saricil, F. (2016). The effect of patient qualifications and number of patient accompanist on patient's satisfaction. Turkish Journal of Emergency Medicine, 16(3), 93-97. https://doi.org/10.1016/j.tjem.2016.02.010

[27] Kotler, Philip dan Keller, 2007, Manajemen Pemasaran, Jilid I, Edisi Kedua belas, PT. Indeks, Jakarta.

[28] Lee, S., \& Kim, E. K. (2017). The Effects of Korean Medical Service Quality and Satisfaction on Revisit Intention of the United Arab Emirates Government Sponsored Patients. Asian Nursing Research, 11(2), 142-149. https://doi.org/10.1016/j.anr.2017.05.008

[29] Lukman, Sampara, 2003, Manajemen Kualitas Pelayanan, Jakarta, STIA LAN Press.

[30] Metta Primaningtyas (2012), Pengaruh Aksesibilitas, Atribut Fisik, Kesehatan Lingkungan Dan Fasilitas Publik Terhadap Kepuasan Bermukim (Studi Kasus Pada Pt. Armada Hada Graha Magelang) Jurnal Sains Pemasaran Indonesia Volume Xi, No. 3, Desember 2012, Halaman 283 300.

[31] Mira Taufik dkk, (2015) Perbandingan Kepuasan Pasien Terhadap Pelayanan Kesehatan Menurut Aksesibilitas Wilayah (Kasus Kecamatan Sungai Lilin dan Kecamatan Tungkal Jaya Kabupaten Musi Bayu Asin Sumatra Selatan. MGI Vol. 29, No.2 September 2015 (154-162).

[32] Maria Imelda Beku (2013, Faktor-Faktor Yang Berhubungan Dengan Kepuasan Pasien Tentang Pelayanan Di Puskesmas Boawae Kecamatan Boawae Kabupaten Nagekeo

[33] Muhammad, Ali, 2010, Kesehatan Wanita,Gender dan Permasalahannya", Nuha Medika, Yogyakarta.

[34] Nahid, K. K., Mojgan, L., Hasantehran, T., \& Fatemeh, P. S. (2012). The effective factors on satisfaction from the view point of patients at the emergencywards in tabriz emam and sina hospitals, (2010). Procedia - Social and Behavioral Sciences, 31(2011), 750-755. https://doi.org/10.1016/j.sbspro.2011.12.135

[35] Ni Kadek Suari Suma Dewi (2014) Pengaruh Aksesibilitas Terhadap Kepuasan Pasien Di Rumah Sakit Gigi Dan Mulut Fakultas Kedokteran Gigi Universitas Mahasaraswati Denpasar.

[36] Nurachmah, E. 2005.Asuhan Keperawatan Bermutu Di Rumah Sakit . Available:Http www. Fikui. Or. Id. 05 01-2008

[37] Nazriah, 2009. Konsep Dasar Kebidanan. Banda Aceh : Yayasan Pena

[38] Patandianan, S., Ratnawati, T., \& Sardjono, S. (2018). Influence Of Capital Funds, Infrastructure Means, And Professionalism Human Resources On Service Quality And Patient Satisfaction Of Puskesmas District Polewali Mandar West Sulawesi. Archives of Business Research, 6(2), 10-18. https://doi.org/10.14738/abr.62.4160

[39] P. Siagian, Sondang.2002. Kepemimpinan Organisasi \& Perilaku Administrasi,. Jakarta: Penerbit Gunung Agung. Pabundu Tika,2006.

[40] Prihantoro, Rudy, 2012, Konsep Pengendalian Mutu, Remaja Rosdakarya, Bandung

[41] Peraturan Menteri Kesehatan RI Nomor HK.02.02/148/I/2010, Izin dan Penyelenggaraan Praktik Perawat.

[42] Purwandani, D., Sutarsih, C., \& Sururi. (2014). Pengaruh Mutu Layanan Sarana dan Prasarana Terhadap Kepuasan Mahasiswa di Fakultas Pendidikan Teknologi dan Kejuruan Universitas Pendidikan Indonesia. Jurnal ADPEND, 80-90.

[43] Ristiani, I. Y. (2017). Pengaruh Sarana Prasarana dan Kualitas Pelayanan Terhadap Kepuasan Pasien (Studi Pada Pasien Rawat Jalan Unit Poliklinik IPDN Jatinegoro). Jurnal Coopetition, 8(2), 155166.

[44] Rendy, Clevo.2013.Keterampilan Dasar Keperawatan. Yogyakarta: Nuha Medika 
[45] Robbins, Stephen P. Perilaku Organisasi. Edisi kesepuluh. alih bahasa: Benyamin Molan. Jakarta: Indeks. 2007.

[46] Rita Fahdila Sumantri (2012) Kompetensi Pengelolaan Pembelajaran, Kecerdasan Interpersonal, Komitmen, Dan Kepuasan Kerja Guru Smk. Jurnal Ilmu Pendidikan, Jilid 18, Nomor 1, Juni 2012, hlm. 30-35.

[47] Rahma Indrawati (2016) Pengaruh Kompetensi Dan Kualitas Pelayanan Petugas Puskesmas Terhadap Kepuasan Pasien Di Puskesmas Ciledug - Tangerang.

[48] Ririn, A. 2007. "Masalah Kurangnya Mutu Pelayanan Puskesmas Ditinjau Dari Sarana Petugas Pemberi Pelayanan Serta Program Dinkes"./http://www. spicecoments.co.

[49] Rendy,Clevo.2013.Keterampilan Dasar Keperawatan. Yogyakarta: Nuha Medika.

[50] Rangkuti, Freddy, 2003, Measuring Customer Satisfaction: Teknik Mengukur dan Strategi Meningkatkan Kepuasan Pelanggan, Gramedia Pustaka Utama, Jakarta

[51] Serrat, O. (2017). Marketing in the Public Sector. Knowledge Solutions, (January), 111-118. https://doi.org/10.1007/978-981-10-0983-9_16

[52] Shin, N., \& Park, J. (2018). The Effect of Intentional Nursing Rounds Based on the Care Model on Patients' Perceived Nursing Quality and their Satisfaction with Nursing Services. Asian Nursing Research, 12(3), 203-208. https://doi.org/10.1016/j.anr.2018.08.003

[53] Syaiful F.Prihadi, (2004). Assesment Centre, Gramedia Pustaka Utama, Jakarta.

[54] Sumantri, R. F. (2012). Kompetensi Pengelolaan Pembelajaran, Kecerdasan Interpersonal, Komitmen, dan Kepuasan Kerja Guru SMK. Jurnal Ilmu Pendidikan, 18(1), 30-35.

[55] Sutantono, Bambang. 2004. Langkah Kecil Yang Kita Lakukan Menuju Transportasi Yang Berkelanjutan. Jakarta: Masyarakat Transportasi Indonesia.

[56] Saludung. 2002. Penilaian dan Peningkatan Kepuasan Pasien. Jakarta.

[57] Tjiptono, Fandy \& Gregorius Chandra, 2005.Service, Quality \& Satisfaction. Yogyakarta: Penerbit Andi.

[58] Wibowo, 2007. Manajemen Kinerja. Jakarta : PT. Raja Grafindo Persada. 